\title{
A Professional Development Program for Developing In-Service Preparatory Stage EFL Teachers' Performance in the Light of their Teaching Needs
}

\author{
Laila Hashem*
}

\begin{abstract}
This study aimed at investigating the effect of a professional development program on inservice preparatory stage EFL teachers' performance in the light of their teaching needs. Three main instruments were administered to twenty male and female teachers (a questionnaire, an achievement test and an observation sheet) who represented the experimental group (10) and the control group (10). The professional development program was administered for eight weeks. The data, collected in terms of a range of measures of seven knowledge aspects and four main teaching skills were subjected to t-test. The results indicated that, after the implementation of the program, the participants achieved higher levels in the post-administration of the achievement test as well as in the post-administration of the observation sheet than in the pre-administration of both of them. Moreover, the participants achieved higher levels in the post-administration of the achievement test as well as in the post-administration of the observation sheet than the control group. The results highlighted the positive effect of the suggested program based on teachers' teaching needs on developing teachers' knowledge aspects and teaching skills. The program enabled the participants to gain deeper insights into themselves and the courses they taught. It also enabled teachers to update their knowledge and skills, and thus review their teaching practices.
\end{abstract}

Keywords: professional development program/ performance / teaching needs.

\section{Introduction}

Teachers are considered an essential part in the development of the educational process. So, "Teachers need regular opportunities to update their professional knowledge and skills" (Richards, 2015:695). Those opportunities are represented in the form of well-planned and documented professional development programs. Consequently, teachers' training should be revised continuously in order to provide them with effective professional development programs that can foster their teaching performance in class.

Effective professional development programs have a positive feedback of influence not only on teachers' performance, but also on their students' learning. Thus, "Professional development not only updates the knowledge and skills for teachers, but also increases the productivity and potential of the teachers as well as students' achievements" (Muzaffar \& Malik, 2012: 308). So, professional development is considered "an ongoing process in which

\footnotetext{
* Lecturer - department of Curriculum and Instruction Faculty of Graduate Studies for Education Cairo University

Email : lailalismail2010@yahoo.com
} 
teachers review their teaching practices and learn how to respond to their students' needs" (Yurtseven, 2017: 120).

For EFL teachers, the challenge, then, is to provide teachers with effective professional development that would increase their professional knowledge and language skills (Young, Freman, Hauck, Gamez \& Papageogriou, 2014: 16).

\section{Aim of the research}

The current research was conducted to investigate the effect of a professional development program on in-service preparatory stage EFL teachers' performance in the light of their teaching needs.

\section{Context of the problem}

The researcher of the current research administered a needs-analysis questionnaire to sixty inservice preparatory stage EFL teachers who worked at Giza preparatory stage governmental schools in order to identify their needs. The results of the questionnaire clarified clearly that teachers' opinions are crucial for constructing effective professional development programs based on their actual teaching needs. The teachers selected seven aspects out of twelve as the most essential issues that require further attention in the professional development programs introduced to them.

Added to the results of the questionnaire, the researcher worked as a teacher of English Language in preparatory schools for five years. She attended, with her colleagues, several professional development programs which did not completely fulfill their specific teaching needs.

Moreover, the results of the previous studies assured the importance of identifying in-service EFL teachers' needs in order to construct meaningful and motivating professional development programs for them.

\section{Statement of the problem}

The problem of the research could be stated in the need of in-service preparatory stage EFL teachers of a professional development program that was constructed in the light of their teaching needs.

Consequentially, the current research attempted to answer the following research questions:

1. What are the teaching needs of in-service preparatory stage EFL teachers?

2. What are the assumptions upon which a professional development program is constructed for in-service preparatory stage EFL teachers?

3. What are the components of the program?

4. What is the effect of the program implementation on teachers' performance on the professional achievement test?

5. What is the effect of the program implementation on teachers' performance on the skills observation sheet? 


\section{Research variables}

\section{The independent variable}

The professional development program constructed for in-service preparatory stage EFL teachers in the light of their teaching needs.

\section{The dependent variable}

The performance of in-service preparatory stage EFL teachers.

\section{Research Hypotheses}

1. There are significant differences at 0.05 level between the pre-and-post-test mean scores of the experimental group in the achievement test, in favor of the post-test.

2. There are significant differences at 0.05 level between the post-test mean scores of the control group and the experimental group in the achievement test, in favor of the experimental group.

3. There are significant differences at 0.05 level between the pre-and-post-observation sheet mean scores of the experimental group in favor of the post-observation sheet.

4. There are significant differences at 0.05 level between the post-observation sheet mean scores of the control group and the experimental group in favor of the experimental group.

\section{Significance of the research}

The current research attempted to:

1. Divert the attention towards the importance of identifying EFL teachers' needs in order to construct meaningful and motivating professional development programs for them.

2. Shed the light on in-service preparatory stage EFL teachers' knowledge aspects and teaching skills that need to be developed and assessed periodically.

3. Pave the way for other studies that tackle EFL teachers' professional development programs.

\section{Definition of terms}

\section{Professional development programs}

Shehata and El Nagger (2003: 95) defined the in-service professional development programs as "educational opportunities available for teachers to improve their professional skills, cultural skills, and academic skills, and develop their performance, behavior, and positive attitudes towards the profession".

Mohamed (2013: 11) defined them as "any purposeful practice regarding the EFL teachers that helps them develop their skills in the process of teaching and learning".

The researcher of the current research defined them as purposeful practices that help inservice EFL teachers to improve their academic knowledge and teaching skills inside the classroom.

\section{Teaching needs}

Zoheer (2013: 12) defined teaching needs as "knowledge, abilities, behavior, skills and beliefs teacher of EFL has to possess either in language or methodology. Skills that are highly 
required for English teachers to develop performance and cope better with the demands of their profession".

Al-Qahtani (2015: 128) defined them as "the target language needs which stand for improving and maintaining English teacher proficiency, and the pedagogical needs which stand for gaining knowledge and skills for language teaching”.

The researcher of the current research defined them as knowledge and skills preparatory stage EFL teachers need to possess and develop continuously in order to cope with the demands of their profession.

\section{Review of literature and related studies}

There is a number of studies that tackled teachers' teaching needs and professional development programs and other related problematic issues. These studies are classified according to purpose to:

1) studies concerned with identifying the opinions and attitudes of teachers towards the professional development programs (descriptive studies).

2) studies concerned with investigating the effectiveness of a specific professional development program (experimental studies).

Concerning the first type of studies, El-Okda (2010) sought to identify the bases upon which a framework for the professional development of EFL preparatory stage teachers can be designed, teachers' professional development needs as perceived by teachers, and the features of the proposed framework for teachers' professional development. The study was descriptive. The instruments used were a semi-structured interview and a questionnaire administered to 136 preparatory stage EFL teachers from three educational directorates. The results of the study proved that the teachers' level of reflection was very low. They highly valued their need for support to become reflective teachers, as well as their need for language improvement and teaching skills courses.

In his study, Muzaffar (2012) explored the attitude of post-graduate teachers of six public universities at Pakistan towards professional development trainings. The study was descriptive. A questionnaire that had both open and closed items was used for data collection. Data analysis indicated that majority of the teachers attended professional development trainings just for the sake of getting certificates. Thus, some methods were suggested by the teachers through which they could be motivated to take interest in the professional development trainings, such as increasing awareness towards the usefulness of those trainings, and monitoring the teachers' work after training.

Abdel Hady's study (2013) also aimed at designing a professional development program for primary school EFL teachers. The study used two questionnaires, an interview and an observation rubric. It followed the descriptive method. Sample of the study consisted of thirty primary school English Language teachers from three governorates. Finding of the study clarified that some professional development programs were irrelevant to primary school EFL teachers' professional needs. 
Another study by Al-Qahtani (2015) investigated the attitudes of the English teachers towards teachers' professional development at Saudi Arabia, identifying the needs of the English Language teachers of teachers' professional development, and clarifying the challenges that could face English teachers throughout their teachers' professional development. The study was descriptive, and the sample of the study consisted of forty teachers. Two instruments were used: a questionnaire and a semi-structed interview. The findings of the study indicated that teachers' professional development is essential and effective. In addition, teachers' professional development should not only provide knowledge and skills to teachers, but also improve and maintain teachers' English proficiency.

Tawalbeh (2015) explored the EFL teachers' perceived effectiveness of current professional development programs held at Taif University English Language Center in Saudi Arabia. The study was descriptive. A questionnaire of 4-Likert Scale and open-ended questions were used to gather data from seventy-six teachers. The results indicated that teachers had a negative attitude towards the professional development programs held at their English Language Center. Their general attitude showed that their actual needs were not considered when developing the programs. They were mainly passive listeners, and the presenters were not professional enough to handle certain essential topics. Teachers required that a needs assessment should be carried out and electronic professional development would be a good alternative to traditional meetings. Based on the results, the researcher drew certain conclusions and remedial recommendations.

In her study, Yursteveren (2017) examined the perceptions and perspectives of the teachers about their concept of professional development. The study was descriptive. An electronic form was used as a data collection instrument in the study. The participants of the study were 526 different Turkish teachers. The researcher recommended that teachers should learn the current trends, contemporary approaches to teaching and update their knowledge. Moreover, teachers needed to take a positive role during the professional development and monitor their own experiences.

Concerning the second type of studies, Sleem (2009) aimed at designing and implementing methodological program to facilitate language teaching, meet in-service EFL secondary stage teachers' specific needs and develop their skills. The instruments were a teachers' needs inventory, a language test and an observation sheet. It used the one group experimental prepost design. It was task-based as it encouraged ten trainees to interact and collaborate with each other to accomplish the tasks of each session. The training program proved a high effectiveness in upgrading the linguistic and methodological skills of the experimental group as it was based on teachers' actual needs.

Another study by Mahmoud (2011) attempted to investigate the effectiveness of using learning circles on developing thirty in-service preparatory stage EFL teachers' teaching skills. The researcher used the quasi-experimental method which lasted for eight weeks. The instruments of the study were a questionnaire of main skills and subskills of teachers' performance, and a classroom observation card. Results showed that using learning circles- 
based program was effective on developing the experimental group performance skills, especially classroom management and evaluation skills than the control group.

Another study for Zoheer (2013) sought to develop EFL teachers' performance at Sana'a secondary schools in the light of their professional and specialist needs. Based on these needs, the researcher designed a training program. The program was implemented over a period of seven weeks on a group of twenty-five EFL secondary stage teachers. Besides an observation checklist, a pre-post achievement test was used to assess the knowledge aspects of the EFL secondary stage teachers' professional and specialist performance. Results proved that there were significant differences between the mean scores of the experimental group on the observation checklist and the achievement test in favor of the post administration of both of them.

Finally, Giraldo (2014) investigated the effect of a proposed professional development program on six novice in-service English Language teachers' classroom performance. The teachers worked at a language institute at a Colombian state university. A questionnaire was administered to identify teachers' needs. An informal interview, a classroom observation sheet and a semi-structured interview were also used. Five problematic areas emerged which became the main area to be developed by the program workshops: awareness of teacher's own classroom practice, current language teaching methodologies, importance of student's motivation and participation in class, approach to grammar teaching and strategies for different learning styles. Results of the research proved that the experimental group teachers reached a more integral view of language, and presented more coherent lessons than before the implementation of the program.

Based on the above-mentioned studies, the current research attempted to construct and implement a professional development program for developing in-service preparatory stage EFL teachers' performance in the light of their teaching needs.

\section{Method \\ Design}

The quasi-experimental design was used in the current study. The study adopted the equivalent-group design. The suggested professional development program was administered to a group of experimental in-service preparatory stage EFL teachers, whereas the control group teachers did not attend the program. The treatment consisted of eight sessions. Each session lasted for two hours per week.

\section{Participants}

The experimental and control groups were in-service preparatory stage EFL teachers $(\mathrm{N}=20)$ who worked in two intact schools at Al-Haram Educational Directorate. They were assigned randomly. Ten teachers represented the experimental group, whereas the other ten represented the control group. The program was implemented during the second semester of the scholastic year: $2018 / 2019$. 


\section{Instruments for Data Collection}

\section{A. A Questionnaire}

- Objective

The questionnaire aimed at identifying teachers' opinions about the aspects that should be implemented in the suggested professional program.

\section{- Description}

The questionnaire was a 4 Likert scale. The initial version of the questionnaire contained twelve topics. Seven topics only were selected by the teachers.

\section{- Validity}

To ensure the validity and suitability of the questionnaire items, it was submitted first to specialized jury members in the field of curriculum and EFL instruction. The questionnaire was modified according to their recommendations and suggestions*.

\section{- Administration}

The questionnaire was administered to sixty in-service preparatory stage EFL teachers who worked at Giza preparatory stage governmental schools, Al-Haram Educational Directorate, namely El-Faisalia Prep Schools, Hadaiek El-Ahram Prep Schools, and Mohamed Salama Prep Schools. The questionnaire was administered during the first semester of the scholastic year: 2018/2019. The results of the questionnaire were treated statistically, and seven aspects were assigned for the suggested professional program.

* Names of the jury members:

- Prof. Manal Abdel Aziz, Professor of Curriculum and EFL Instruction, Girls' College, Ain Shams University.

- Dr. Amira Khater, Associate Professor of Curriculum and EFL Instruction, Girls' College, Ain Shams University.

- Dr. Hanan Hussein, Associate Professor of Curriculum and EFL Instruction, Girls' College, Ain Shams University.

\section{B. A Pre-Post achievement test}

\section{- Objectives}

The achievement test aimed at measuring teachers' knowledge of the selected aspects related to their professional field, namely:

1. Current language teaching approaches.

2. How to prepare a good lesson plan.

3. How to manage classrooms and relationships.

4. Learners' learning styles.

5. Current methods of how to teach English as a foreign language.

6. Testing and assessment of learners.

7. How to increase learners' motivation and involvement in class.

The test was implemented twice as a pre and post test instrument to evaluate the progress that happened in the experimental group teachers' professional knowledge. 


\section{- Description}

The test was prepared by the researcher of the current research. It contained three types of questions, ten multiple choices (M.C.Q), followed by ten correction items and ten completion items. So, each selected knowledge aspect was measured at least three times. The total score of the test was (60).

\section{- Test validity}

To ensure the test content validity, the initial version was delivered to specialists in the field of Curriculum and EFL Instruction to assess it in terms of content appropriateness, number of items and their suitability to preparatory stage teachers.

- Test reliability

To ensure the test reliability, the test-retest method was administered with an interval of two weeks on twenty in-service preparatory stage EFL teachers other than the sample of the study. Those twenty teachers were enrolled in the general diploma of education at Cairo University during the first semester of the academic year 2018/2019. The reliability coefficient was 0.87 , which is considered relatively high.

\section{- Test scoring}

The items of the test questions were objective, so they did not require another rater. For the multiple-choice questions, the correction questions and the completion questions: (2) scores were given for the correct answers, and (0) score for left or incorrect ones.

\section{- Test duration}

To estimate the test duration, it was administered to ten in-service preparatory stage EFL teachers who were enrolled in the General Diploma of Education at Cairo University during the first semester of the academic year 2018/2019.

Test duration was estimated by calculating the time spent by the fastest and the slowest teachers in answering the test divided by 2 . Thus, the time allotted for the test was $\frac{75+45}{2}=60$ minutes. (see table (A) for test specifications)

Table (A)

Test Specifications

\begin{tabular}{|c|c|c|c|c|c|}
\hline \multirow[b]{2}{*}{ Aspects } & \multicolumn{3}{|c|}{ Question Type } & \multirow[b]{2}{*}{$\begin{array}{l}\text { Number of } \\
\text { items for } \\
\text { each aspect }\end{array}$} & \multirow[b]{2}{*}{$\begin{array}{l}\text { Scores } \\
\text { assigned to } \\
\text { each aspect }\end{array}$} \\
\hline & $\begin{array}{l}\text { Multiple } \\
\text { Choice } \\
\text { Question } \\
\text { (M.C.Q.) }\end{array}$ & Correction & Completion & & \\
\hline $\begin{array}{l}\text { 1. Current language teaching } \\
\text { approaches. }\end{array}$ & 2 & 2 & 2 & 6 & 12 \\
\hline 2. How to prepare a good lesson plan. & 1 & 1 & 1 & 3 & 6 \\
\hline $\begin{array}{l}\text { 3. How to manage classrooms and } \\
\text { relationships. }\end{array}$ & 1 & 1 & 1 & 3 & 6 \\
\hline 4. Learners' learning styles. & 1 & 1 & 1 & 3 & 6 \\
\hline $\begin{array}{l}\text { 5. Current methods of how to teach } \\
\text { English as a foreign language. }\end{array}$ & 2 & 2 & 2 & 6 & 12 \\
\hline 6. Testing and assessment of learners. & 2 & 2 & 2 & 6 & 12 \\
\hline $\begin{array}{l}\text { 7. How to increase learners' } \\
\text { motivation and involvement in } \\
\text { class. }\end{array}$ & 1 & 1 & 1 & 3 & 6 \\
\hline Total & 10 & 10 & 10 & 30 & 60 \\
\hline
\end{tabular}




\section{The observation sheet}

\section{- Objective}

The observation sheet aimed at evaluating the performance of the teachers' skills in class.

\section{- Description}

The observation sheet was adopted from the Education Reform Program (SCOPE) held in Egypt (2003 - 2009). The instrument and its rubric were designed by experts from both the Education Reform Program and the Ministry of Education to be used as an observation instrument for teachers of all subjects (2008 - 2009). It was modified linguistically by the researcher to suit preparatory stage EFL teachers.

The instrument consisted of (4) main skills and (17) items measuring (17) teachers' performance subskills inside the classroom. The total score of the sheet was (80). Each behavioral practice took 5 points according to the SCOPE rubric: classroom management skills (15), using various teaching methods skills (35), developing learners' higher thinking order skills (15), evaluation and giving feedback skills (15).

- The observation sheet validity

To establish the validity of the instrument, it was shown to specialists in the field of Curriculum and EFL Instruction. It was evaluated in terms of linguistic appropriateness, fitness and applicability of the items.

\section{- The observation sheet reliability}

To establish the reliability of the instrument, the agreement between the researcher's and the assigned school senior teacher's observation scores was calculated. Coper formula for agreement and disagreement was used. Agreement percentage = number of agreement scores $\times 100$. Gaber (2002:69) assured that Coper determined number of agreement+number of disagreement
the accepted reliability percentage of $85 \%$ and above as agreement.

The highest agreement percentage between the observers of eight English Language teachers was (92.41), the lowest one was (86.63) which proved high reliability of the instrument.

\section{- The observation sheet duration}

The instrument implementation time was 45 minutes (a whole class period). It was implemented twice as a pre and post observation instrument to evaluate the progress that happened in the experimental group teachers' performance skills.

\section{The Suggested Program}

\section{Description of the program}

The program consisted of eight sessions. Each session lasted for two hours per week. It was implemented during the second semester of the scholastic year 2018/2019.

\section{Assumptions of the program}

The program was built on the following assumptions:

1. Teachers need regular opportunities to develop their professional knowledge and skills.

2. Those opportunities should be connected with teachers' actual needs. 
3. Teachers should play active roles in their professional development.

4. Collaboration among teachers in acquiring knowledge and experience is an essential source of professional growth.

5. Professional development benefits learners, schools, as well as teaches who work at those schools.

\section{General goal and objectives}

\section{a. General goal}

This study aimed at investigating the effect of a suggested professional development program on in-service preparatory stage EFL teachers' performance in the light of their teaching needs.

\section{b. Specific objectives}

At the end of the program, teachers would indicate sufficient knowledge in the following seven aspects:

1. Current language teaching approaches (e.g.: Task-based Language Teaching, The Multiple-Intelligences Theory).

2. How to prepare a good lesson plan.

3. How to manage classrooms and relationships.

4. How to deal with learners' different learning styles.

5. Current methods of how to teach English as a foreign language (e.g.: The Problem Solving Method, The Project Method).

6. How to test and assess learners.

7. How to increase learners' motivation and involvement in class.

Teachers would also indicate sufficient teaching skills in the following four main skills:

- Classroom management.

- Using various teaching methods.

- Developing learners' higher thinking order skills.

- Evaluation and giving feedback.

\section{Validity of the program}

The program was shown to specialized jury members in the field of Curriculum and EFL Instruction to evaluate it in terms of content appropriateness, length, structure, texts, activities, methods of teaching and instructional aids. As a result, it was modified according to their recommendations.

\section{Training Intervention}

The program mainly adopted discussions, individual and co-operative groupwork as its teaching methods.

Before the implementation of the program, there was an introductory session to clarify its objectives and procedures. In addition, methods of evaluation were also explained to the teachers.

To achieve the general goal and objectives of the program, each session contained three stages as follows: 
- The first stage: in the first stage, teachers began brainstorming ideas and opinions about one of the assigned program's aspects. Sometimes, the researcher interfered to activate their interaction.

- The second stage: in the second stage, teachers were given worksheets about one of the assigned aspects followed by relevant questions. They worked individually in order to read the worksheets. Then, they worked in groups, discussing specific sentences that interested or puzzled them, and answering the questions about the aspect.

- The third stage: in the third stage, the researcher generated a discussion with all the teachers about the worksheets and the questions. She asked the teachers additional questions related to the assigned aspect, requiring them to answer them, clarifying their viewpoints and defending them.

\section{Instructional Aids}

The following aids were used during the implementation of the current program:

1. The whiteboard.

2. Data show.

3. The teachers' worksheets that included relevant questions.

\section{Evaluation}

The evaluation system of the teachers' professional development program was summative. Summative evaluation was conducted at the beginning and at the end of the implementation of the suggested program in the form of a pre-post achievement test for measuring teachers' acquired professional knowledge, and a pre-post observation sheet for measuring the effect of the program on teachers' teaching performance in class.

\section{Data Analysis and Results}

Data analysis and results would be tackled in the light of the study hypotheses.

To test the first hypothesis which stated: "There are significant differences at 0.05 levels between the pre-and-post-test mean scores of the experimental group in the achievement test, in favor of the post-test", paired sample t-test was used. Table (B) shows means, standard deviations and T-values of the experimental group in the pre-and post-achievement test. 


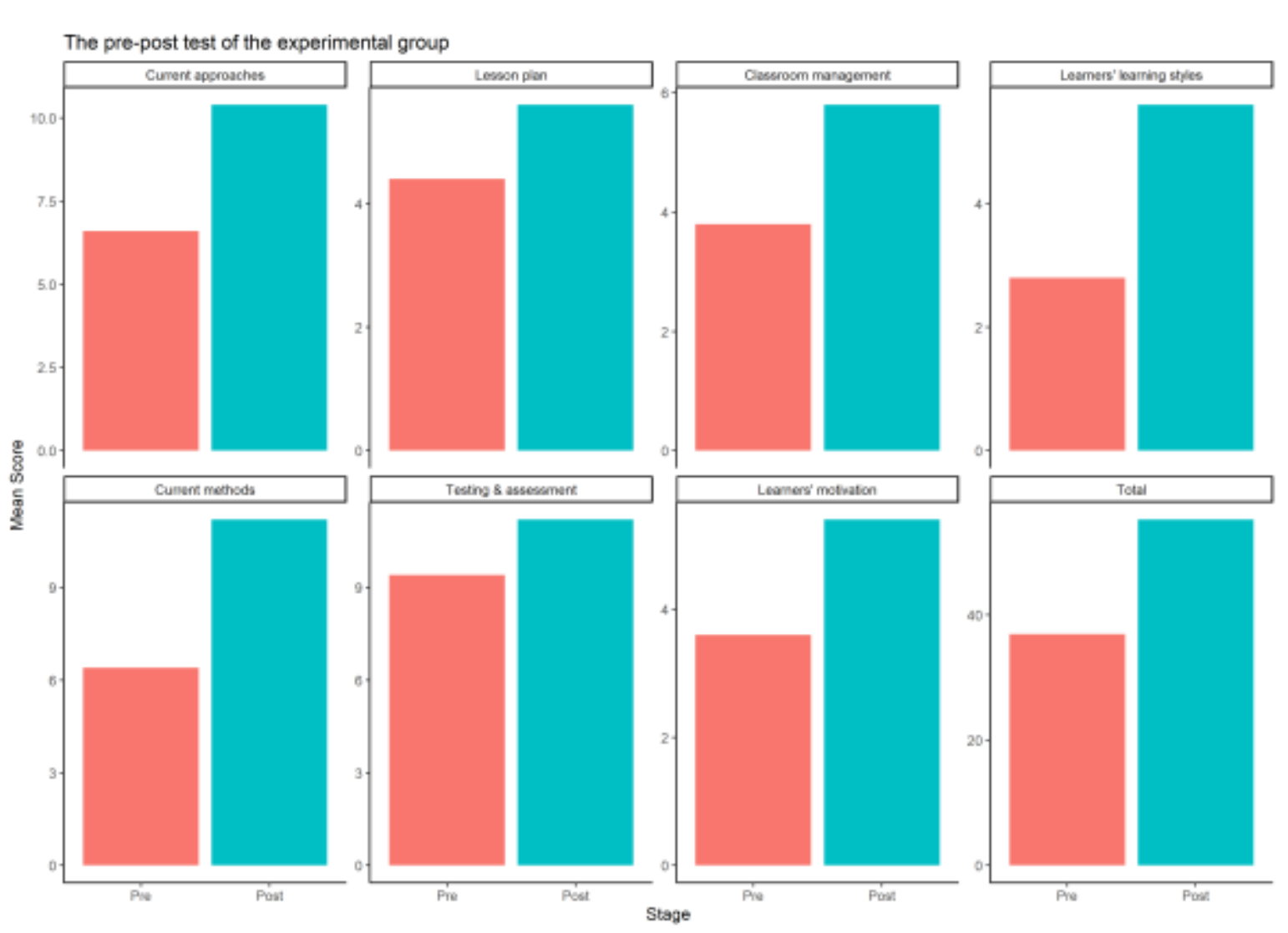

Figure (A)

The Pre-Post Achievement Test Results of the Experimental Group

To test the second hypothesis which stated: "There are significant differences at 0.05 level between the post-test mean scores of the control group and the experimental group in the achievement test, in favor of the experimental group", paired sample t-test was used. Table (C) shows means standard deviations and T-values of the control group and the experimental group in the post-achievement test. 
Table (C)

\section{The Achievement Test Results Comparing Mean Scores of the Post Administration of the Control \& Experimental Groups Achievement Test in all Aspects}

\begin{tabular}{|c|c|c|c|c|c|c|c|}
\hline \multicolumn{8}{|c|}{$(\mathrm{N}=20, \mathrm{DF}=18)$} \\
\hline Aspect & Administration & Mean & Std. Deviation & Std. Error Mean & t-value & Sig.Level & Effect Size (n2) \\
\hline \multirow{2}{*}{$\begin{array}{l}\text { 1. Current } \\
\text { approaches }\end{array}$} & Control & 6.4000 & 2.06559 & 0.65320 & \multirow{2}{*}{4.867} & \multirow{2}{*}{0.000} & \multirow{2}{*}{0.570} \\
\hline & Experimental & 10.4000 & 1.57762 & 0.49889 & & & \\
\hline \multirow{2}{*}{ 2. Lesson plan } & Control & 4.8000 & 1.68655 & 0.533333 & \multirow{2}{*}{1.342} & \multirow{2}{*}{0.196} & \multirow{2}{*}{0.090} \\
\hline & Experimental & 5.6000 & 0.84327 & 0.26667 & & & \\
\hline \multirow{2}{*}{$\begin{array}{l}\text { 3. Classroom } \\
\text { management }\end{array}$} & Control & 4.6000 & 1.34990 & 0.42687 & \multirow{2}{*}{2.546} & \multirow{2}{*}{0.020} & \multirow{2}{*}{0.260} \\
\hline & Experimental & 5.8000 & 0.63246 & 0.20000 & & & \\
\hline \multirow{2}{*}{$\begin{array}{l}\text { 4. Learning } \\
\text { styles }\end{array}$} & Control & 2.8000 & 1.03280 & 0.32660 & \multirow{2}{*}{6.641} & \multirow{2}{*}{0.000} & \multirow{2}{*}{0.710} \\
\hline & Experimental & 5.6000 & 0.84327 & 0.32660 & & & \\
\hline \multirow{2}{*}{$\begin{array}{l}\text { 5. Current } \\
\text { methods }\end{array}$} & Control & 5.4000 & 1.64655 & 0.52068 & \multirow{2}{*}{9.436} & \multirow{2}{*}{0.000} & \multirow{2}{*}{0.830} \\
\hline & Experimental & 11.2000 & 1.03280 & 0.32660 & & & \\
\hline \multirow{2}{*}{$\begin{array}{l}\text { 6. Testing and } \\
\text { assessment }\end{array}$} & Control & 9.4000 & 1.34990 & 0.42687 & \multirow{2}{*}{3.349} & \multirow{2}{*}{0.004} & \multirow{2}{*}{0.384} \\
\hline & Experimental & 11.2000 & 1.03280 & 0.32660 & & & \\
\hline \multirow{2}{*}{$\begin{array}{l}\text { 7. Learners' } \\
\text { motivation }\end{array}$} & Control & 4.0000 & 1.33333 & 0.42164 & \multirow{2}{*}{2.689} & \multirow{2}{*}{0.015} & \multirow{2}{*}{0.290} \\
\hline & Experimental & 5.4000 & 0.96609 & 0.30551 & & & \\
\hline \multirow{2}{*}{ 8. Total } & Control & 37.4000 & 6.60303 & 2.08806 & \multirow{2}{*}{$7.024 *$} & \multirow{2}{*}{0.000} & \multirow{2}{*}{$0.756 *$} \\
\hline & Experimental & 55.2000 & 4.54117 & 1.43604 & & & \\
\hline
\end{tabular}

T-test results proved that there were statistically significant differences at 0.05 level in the total achievement test score and in each aspect. The calculated effect size indicated that the implemented program had a significant effect on the experimental group post performance in the total score, as well as in each aspect.

The largest effect size was for current methods of how to teach English as a foreign language $(0.830)$ with a t-value (9.436). It was followed by learning styles $(0.710)$ with a tvalue (6.641). Then, current language teaching approaches (0.570) with a t-value (4.867). Then, testing and assessment (0.384) with a t-value (3.349). Then comes increasing learners' motivation (0.290) with a t-value (2.689). It is followed by classroom management $(0.260)$ with a t-value (2.546). The lowest effect size was for lesson plan (0.090) with a t-value (1.342). The total effect size of the seven aspects was (0.756) with a t-value (7.024). Thus, the second hypothesis was supported.

For more clarification of the post-achievement test results of the control and the experimental groups, figure (B) was designed. 

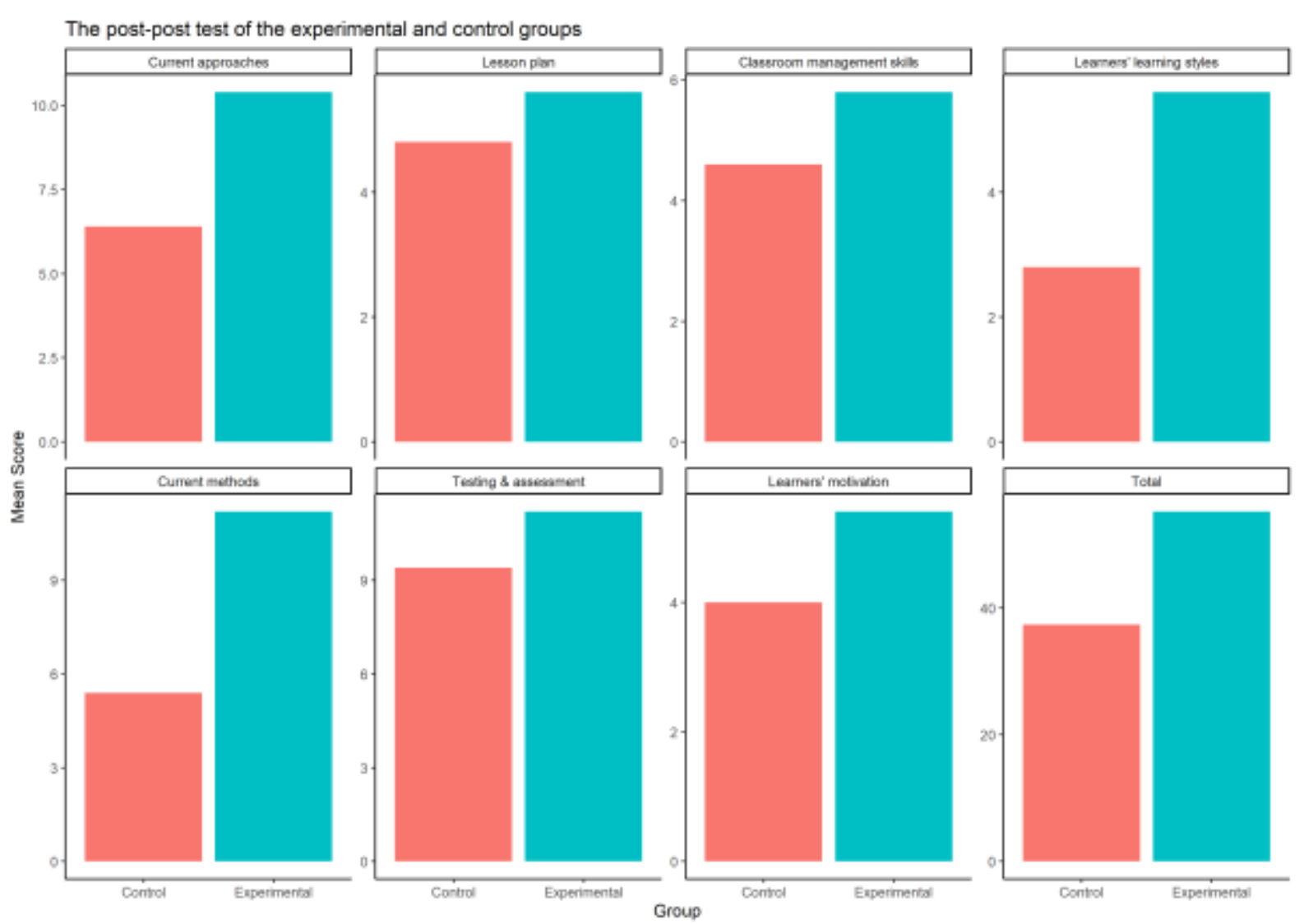

Figure (B)

The Post Achievement Test Results of the Control and Experimental Groups

To test the third hypothesis which stated "There are significant differences at 0.05 level between the pre-and-post-observation sheet mean scores of the experimental group in favor of the post-observation sheet", paired sample t-test was used. Table (D) shows means, standard deviations and T-values of the experimental group in the pre-and-post observation sheet.

Table (D)

The Observation Sheet Results Comparing Mean Scores of the Pre and Post Administration of the Experimental Group in all Main Skills $(\mathbf{N}=10, \mathrm{DF}=9)$

\begin{tabular}{|c|c|c|c|c|c|c|c|}
\hline Main Skill & Administration & Mean & Std. Deviation & Std. Error Mean & t-value & Sig.Level & Effect Size (n2) \\
\hline \multirow{2}{*}{$\begin{array}{l}\text { 1. Clasroom } \\
\text { management }\end{array}$} & Pre & 9.0000 & 1.82574 & 0.57735 & \multirow{2}{*}{13.693} & \multirow{2}{*}{0.000} & \multirow{2}{*}{0.954} \\
\hline & Post & 14.0000 & 1.05409 & 0.33333 & & & \\
\hline \multirow{2}{*}{$\begin{array}{l}\text { 2. Using various teaching } \\
\text { methods }\end{array}$} & Pre & 24.8000 & 3.48967 & 1.10353 & \multirow{2}{*}{8.631} & \multirow{2}{*}{0.000} & \multirow{2}{*}{0.892} \\
\hline & Post & 31.9000 & 1.52388 & 0.48189 & & & \\
\hline \multirow{2}{*}{$\begin{array}{l}\text { 3. Developing learners' } \\
\text { higher thinking order }\end{array}$} & Pre & 9.8000 & 1.87380 & 0.59255 & \multirow{2}{*}{4.609} & \multirow{2}{*}{0.001} & \multirow{2}{*}{0.702} \\
\hline & Post & 12.2000 & 2.09762 & 0.66332 & & & \\
\hline \multirow{2}{*}{$\begin{array}{l}\text { 4. Evaluation and giving } \\
\text { feedback }\end{array}$} & Pre & 11.2000 & 2.39444 & 0.75719 & \multirow{2}{*}{5.218} & \multirow{2}{*}{0.001} & \multirow{2}{*}{0.752} \\
\hline & Post & 13.9000 & 1.10050 & 0.34801 & & & \\
\hline \multirow{2}{*}{ 8. Total } & Pre & 54.8000 & 7.37564 & 2.33238 & \multirow{2}{*}{$9.622 *$} & \multirow{2}{*}{0.000} & \multirow{2}{*}{$0.911 *$} \\
\hline & Post & 72.0000 & 3.88730 & 1.22927 & & & \\
\hline
\end{tabular}


T-test results proved that there were statistically significant differences at 0.05 level in the total post observation sheet score and in each main skill. Furthermore, the calculated effect size indicated that the implemented program had a significant effect on the experimental group post-performance in the total score, as well as in each main skill.

The largest effect size was for classroom management (0.954) with a t-value (13.693). It was followed by using various teaching methods (0.892) with a t-value (8.631). Then, evaluation and giving feedback (0.752) with a t-value (5.218). The lowest effect size was for developing learners' higher thinking order (0.702) with a t-value (4.609). The total effect size of the four main skills was (0.911) with a t-value (9.622). So, the third hypothesis was proved.

For more elaboration of the pre-post observation sheet results of the experimental group, figure $(\mathrm{C})$ was designed.
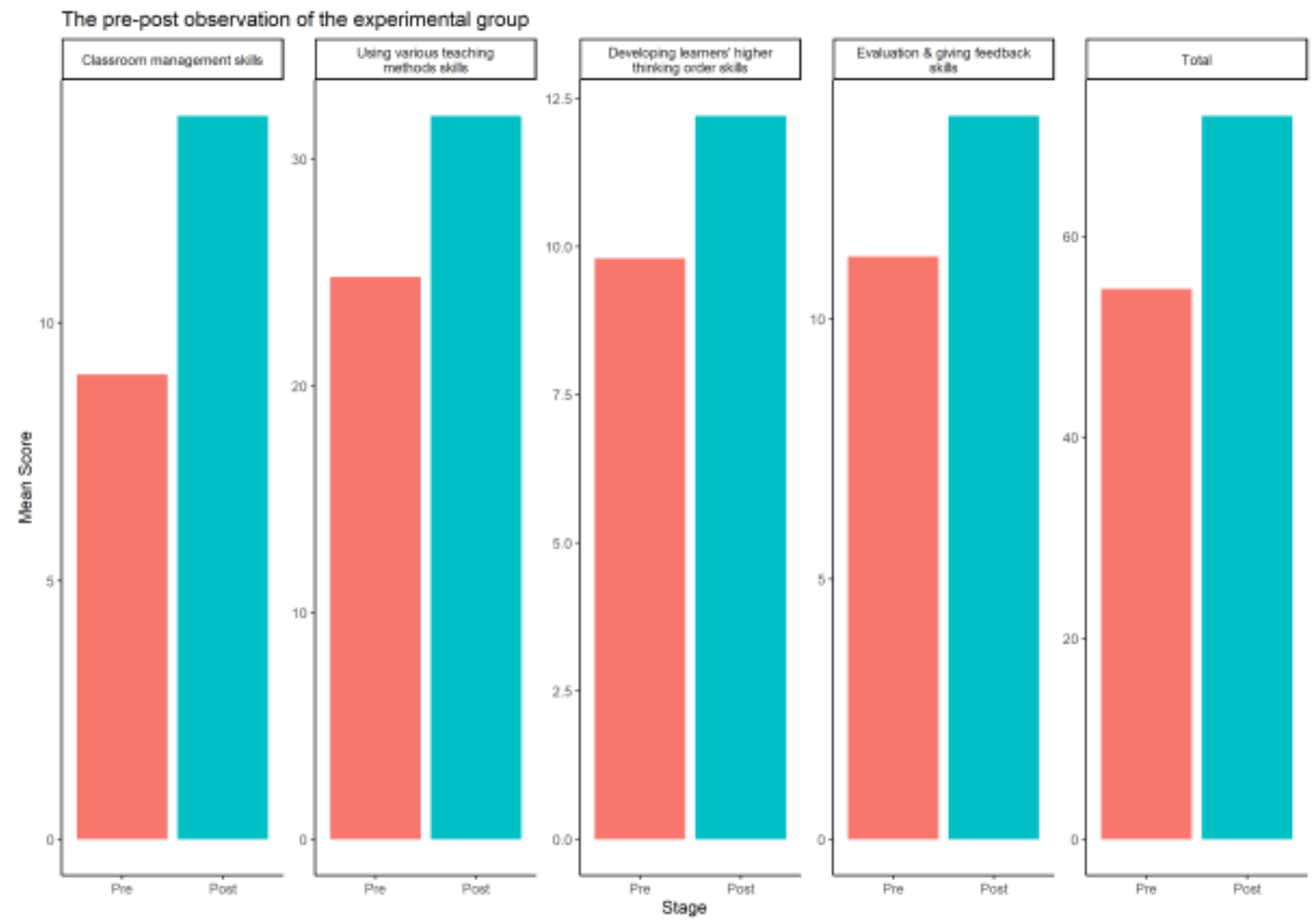

Figure (C)

\section{The Pre-Post Observation Sheet Results of the Experimental Group}

To test the fourth hypothesis which stated: "There are significant differences at 0.05 level between the post-observation sheet mean scores of the control group and the experimental group in favor of the experimental group", paired sample t-test was used. Table (E) shows means standard deviations and T-values of the control and the experimental groups in the post-observation sheet. 
Table (E)

\section{The Observation Sheet Results Comparing Mean Scores of the Post Administration of the Control \& Experimental Groups in all Main Skills}

\begin{tabular}{|c|c|c|c|c|c|c|c|}
\hline \multicolumn{8}{|c|}{$(\mathrm{N}=20, \mathrm{DF}=18)$} \\
\hline Main Skill & Group & Mean & Std. Deviation & Std. Error Mean & t-value & Sig.Level & Effect Size (n2) \\
\hline \multirow{2}{*}{$\begin{array}{l}\text { 1. Clasroom } \\
\text { management }\end{array}$} & Control & 9.2000 & 2.04396 & 0.64636 & \multirow{2}{*}{6.600} & \multirow{2}{*}{0.000} & \multirow{2}{*}{0.708} \\
\hline & Experimental & 14.0000 & 1.05409 & 0.33333 & & & \\
\hline \multirow{2}{*}{$\begin{array}{l}\text { 2. Using various teaching } \\
\text { methods }\end{array}$} & Control & 24.6000 & 3.68782 & 1.16619 & \multirow{2}{*}{5.785} & \multirow{2}{*}{0.000} & \multirow{2}{*}{0.650} \\
\hline & Experimental & 31.9000 & 1.52388 & 0.48189 & & & \\
\hline \multirow{2}{*}{$\begin{array}{l}\text { 3. Developing learners' } \\
\text { higher order of thinking }\end{array}$} & Control & 10.3000 & 2.05751 & 0.65064 & \multirow{2}{*}{2.045} & \multirow{2}{*}{0.056} & \multirow{2}{*}{0.189} \\
\hline & Experimental & 12.2000 & 2.09762 & 0.66332 & & & \\
\hline \multirow{2}{*}{$\begin{array}{l}\text { 4. Evaluation and giving } \\
\text { feedback }\end{array}$} & Control & 11.3000 & 2.58414 & 0.81718 & \multirow{2}{*}{2.927} & \multirow{2}{*}{0.009} & \multirow{2}{*}{0.323} \\
\hline & Experimental & 13.9000 & 1.10050 & 0.34801 & & & \\
\hline \multirow{2}{*}{ 8. Total } & Control & 55.4000 & 8.01665 & 2.53509 & \multirow{2}{*}{$5.892 *$} & \multirow{2}{*}{0.000} & \multirow{2}{*}{$0.659 *$} \\
\hline & Experimental & 72.0000 & 3.88730 & 1.22927 & & & \\
\hline
\end{tabular}

* Significant at 0.05
t-value $=5.892$

T-test results proved that there were statistically significant differences at 0.05 level in the total observation sheet score and in each main skill. The calculated effect size indicated that the implemented program had a significant effect on the experimental group post performance in all skills, as well as in each main skill.

The largest effect size was for classroom management (0.708) with a t-value (6.600). It was followed by using various teaching methods $(0.650)$ with a t-value $(5.785)$. Then, evaluation and giving feedback (0.323) with a t-value (2.927). The lowest effect size was for developing learners' higher thinking order (0.189) with a t-value (2.045). The total effect size of the four main skills was (0.659) with a t-value (5.892). So, the fourth hypothesis was proved.

For more clarification of the post-observation sheet results of the control and the experimental groups, figure (D) was designed. 

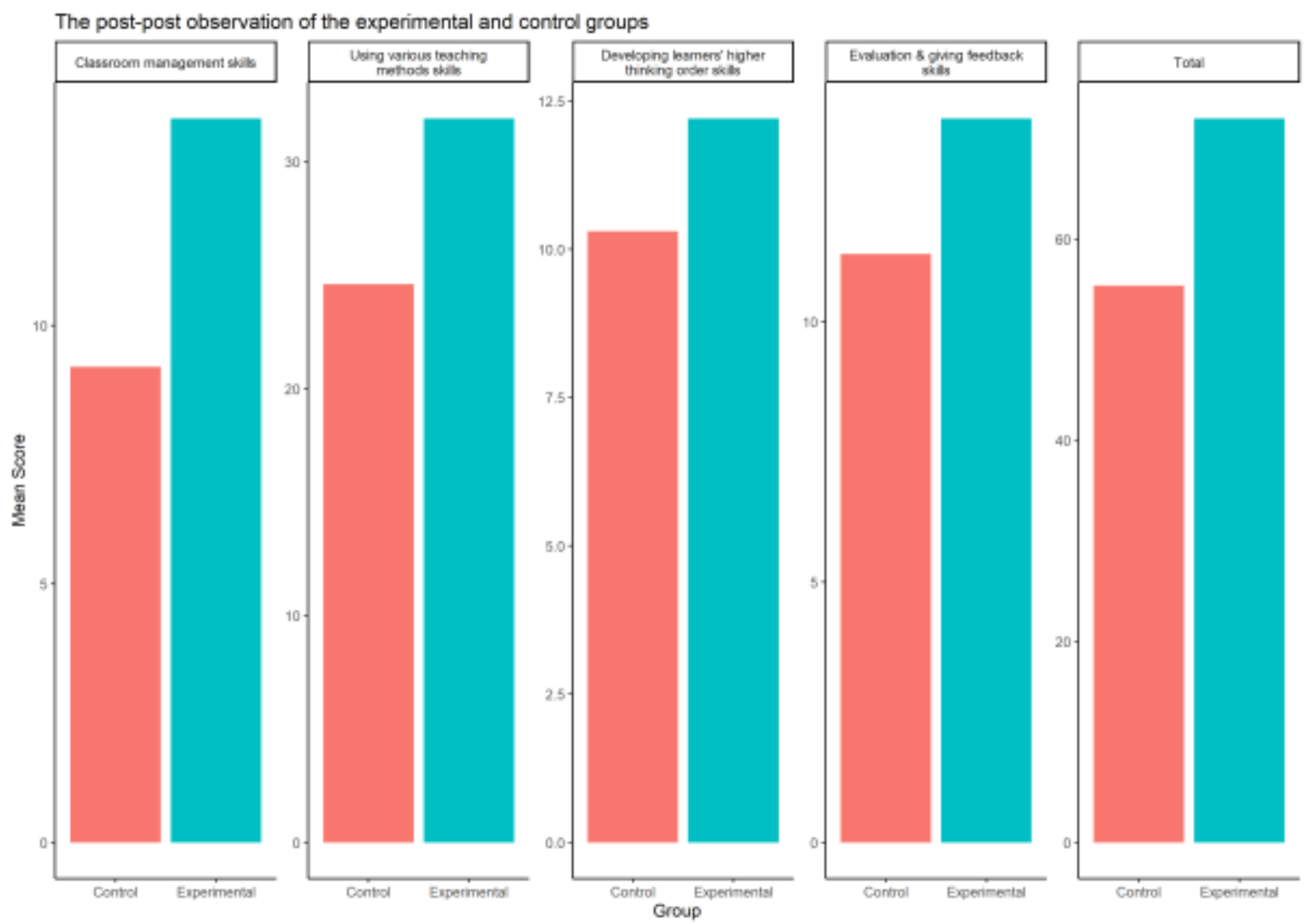

Figure (D)

The Post Observation Sheet Results of the Control and Experimental Groups

\section{Discussion of Results}

First, it has to be mentioned that the researcher of the current research could answer all the research questions which stated:

1. What are the teaching needs of in-service preparatory stage EFL teachers?

2. What are the assumptions upon which a professional development program is constructed for in-service preparatory stage EFL teachers?

3. What are the components of the program?

4. What is the effect of the program implementation on teachers' performance on the professional achievement test?

5. What is the effect of the program implementation on teachers' performance on the skills observation sheet?

The researcher could identify:

- The essential seven dimensions selected by in-service preparatory stage EFL teachers that require further attention in the professional development programs.

- The five assumptions upon which the suggested professional development program was constructed.

- The general goal, specific objectives, methods of teaching, texts, activities, stages of intervention, instructional aids and evaluation system of the program.

The researcher could also statistically reach: 
- The effect of the program implementation on teachers' performance on the professional achievement test.

- The effect of the program implementation on teachers' performance on the skills observation sheet.

Moreover, results of the study indicated that the experimental group teachers' post performance has greatly exceeded their own pre-performance in the seven dimensions of the achievement test as well as the test as a whole. The same results have been proved concerning the observation sheet in total observed skills as well as in each main skill.

Results of the study also indicated that the performance of the experimental group teachers has greatly exceeded the performance of the control group teachers in their postperformance in the seven dimensions of the achievement test as well as the test as a whole. The same result has also been proved concerning the observation sheet in total observed skills as well as in each main skill.

The program with its general goal and specific objectives, content, activities, methods of teaching, instructional aids and evaluation system succeeded in developing teachers' achievement and class performance.

The development in teachers' achievement and class performance is consistent with the results of Sleem's (2009), Mahmoud's (2011), Zoheer's (2013), Giraldo's (2014) and Yursteveren's (2017) studies which proved that identifying teachers' specific needs is essential for constructing effective professional development programs. They also proved that programs should concentrate on certain areas such as current language teaching approaches and methodologies, classroom management, importance of using certain strategies for different learning styles, the importance of enhancing learners' motivation and participation in class and improving the used evaluation and feedback methods. The findings of the current study were also consistent with the findings of some of the previously mentioned studies that teachers need to take a positive role during the implementation of the professional development programs, such as Zoheer's (2013), Giraldo's (2014) and Yursteveren's (2017) studies.

Lastly, it has to be stressed that the program was based on the teachers' needs which had positive effects on their interest, contribution and persistence. On the other hand, the introductory session held before the implementation of the program helped in clarifying the general goal, objectives, content, activities, methods of teaching and evaluation system to the teachers. It enhanced the teachers' interest as it made the program meaningful and motivating for them.

The findings obtained from the previously mentioned studies also agreed with the findings of the current study which reflected that teachers should be helped to update their professional knowledge and improve their teaching skills in class regularly and in a well-planned and documented method.

As for the achievement test results, teachers' knowledge in the selected seven aspects has been obviously improved. The lowest effect size was for lesson plan. This can be 
attributed to the great attention that had already been given beforehand to this aspect by teachers and supervisors.

As for the observation sheet results, teachers' teaching performance in class in the four main skills has also been obviously improved. The lowest effect size was for developing learners' higher thinking order. This can be attributed to the long time needed to observe the improvement in the teachers' teaching performance concerning this main skill.

\section{Recommendations and Suggestions}

Based on the current research results, the following recommendation were suggested:

1. EFL professional development programs should include both knowledge aspects and practical skills that teachers actually need in teaching.

2. Incorporating current trends in English language teaching to reinforce the effectiveness and success of the professional development programs.

3. Implementing learners' different learning styles and how to increase their motivation and participation in class as essential issues to be tackled in the EFL professional development programs.

4. Teachers of English Language should have a positive role during the implementation of the professional development programs.

According to the current research results, the following are suggestions for further research:

1. The effectiveness of other online development program in developing in-service EFL preparatory stage knowledge aspects and teaching skills.

2. The effectiveness of other programs in developing the linguistic performance skills of inservice EFL preparatory stage teachers.

3. The effect of other programs on developing learners' higher thinking order skills.

4. The effect of using self-reflection and peer-observation on developing in-service EFL preparatory stage teachers' teaching skills.

\section{References}

Abdel Hady, A. (2013). Developing the Professional Development Program for Primary School English Language Teachers (unpublished Ph.D. thesis): Cairo University.

Aggarwal, J. (2004). Principles, methods and techniques of teaching. (Fifth ed.). Delhi, India: Vikas Publishing House.

Akcan, S. (2016). Novice non-native English teachers' reflections on their teacher education programs and their first years of teaching. Profile Issues in Teachers' Professional Development, 18 (1), 55-70.

Al-Qahtani, H. (2015). A Needs analysis of teachers' needs for professional development with the emergence of the current English textbooks. English Language Teaching, 6 (8), 128141.

Booth W., Colomb G., Williams J., Bizup J. \& Fitzgerald W. (2016). The craft of research. Fourth edition. Chicago, Illinois, U.S.A: The University of Chicago Press. 
Cheng, L. (2004). Understanding professional challenges faced by Chinese teachers of English. The Electronic Journal for English as a Second Language, 7 (4), 1-14.

El-Okda, H. (2010). A proposed framework for prep stage EFL teachers' professional development in the light of their needs (unpublished M.A. thesis): Faculty of Graduate Studies for Education. Cairo University.

Garcềs A. \& Granada L. (2016). The role of collaborative action research in teachers' professional development. Profile Issues in Teachers' Professional Development, 18 (1), 3954.

Giraldo, F. (2013). The impact of a professional development program on English Language teachers' classroom performance. Profile Issues in Teachers' Professional Development, 16 (1), 63-76.

Harmer, J. (2000). How to teach English. (Sixth ed.). London, U.K.: Pearson Longman.

Hassan E. (2016). Female teachers' professional development through action research practice. Journal of Education and Practice, 7 (22), 6-18.

Hunzicker, J. (2011). Effective professional development for teachers: a checklist. Professional Development in Education, 37 (2), 177-179.

Mahmoud, S. (2011). The Effectiveness of Using Learning Circles on Developing Preparatory Stage English Teachers' Teaching Skills (unpublished M.A. thesis): Faculty of Graduate Studies for Education. Cairo University.

Muzaffar, M. (2012). Attitude of teachers towards professional development trainings. Language in India, 12 (8), 304-322.

Richards J. (2015). Key issues in language teaching. (First ed.). Cambridge. U.K.: Cambridge University Press.

Richards J. \& Rodgers T. (2014). Approaches and methods in language teaching. (Third ed.). Cambridge. U.K.: Cambridge University Press.

Shehata, H. \& El Naggar, Z. (2003). Dictionary of educational and psychological terms. Cairo. Egypt: Al Dar AL Masria Al Lobnania.

Sleem, A. (2009). The Effectiveness of Proposed In-Service Training Program for English Language Teachers in the Secondary Stage on Developing their Linguistic and Methodological Skills in the Light of their Professional Needs (unpublished Ph.D. thesis): Faculty of Graduate Studies for Education. Cairo University.

Tawallbeh, T. (2015). Instructors' perceived effectiveness of current professional development programs at Taif university English Language center. English Language Teaching, 8 (11), 117-130.

Young J., Freeman D., Hauck M., Gomez P. \& Papageorgion S. (2014). A Design framework for the EL teach program assessments. New Jersey. U.S.A: Educational Testing Service. 
Yurtseven, N. (2017). The investigation of teachers' metaphoric perceptions about professional development. Journal of Education and Learning, 6 (2), 120-131.

Zoheer, K. (2013). Developing EFL Teachers' Performance at Sana'a Secondary Schools in the Light of their Professional and Specialist Needs (unpublished Ph.D. thesis): Faculty of Graduate Studies for Education. Cairo University. 
برنامج للتنمية المهنية لتنمية أداء معلمي اللغة الإنجليزية بالمرحلة الإعدادية في ضوء احتياجاتهم التدريسية

\section{دا ليلي هاشم}

مدرس قسم المناهج و التدريس بكلية الدراسات العليا للتربية جامعة القاهرة

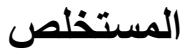

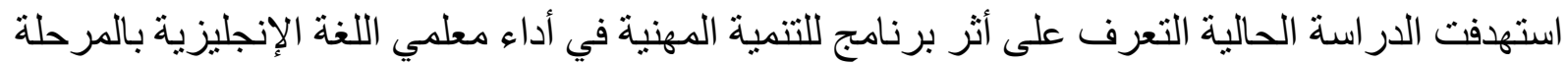

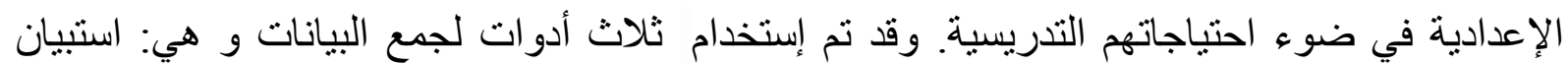

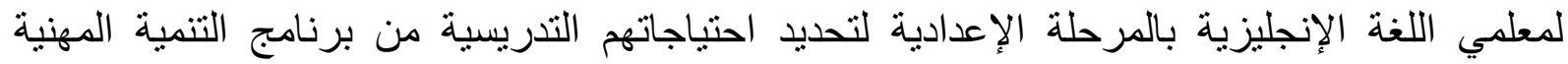

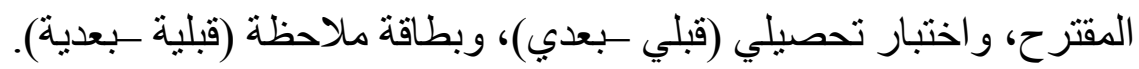

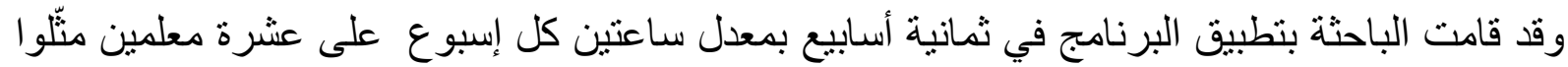

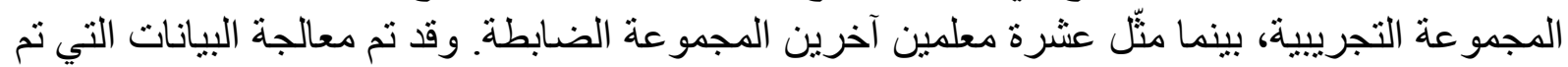

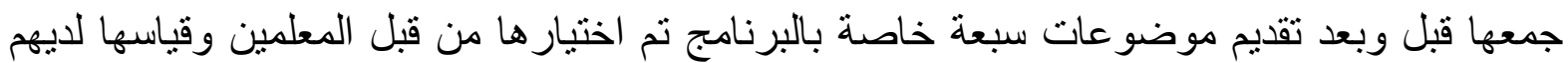

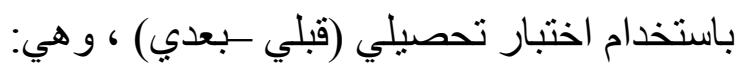

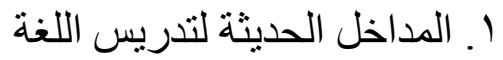

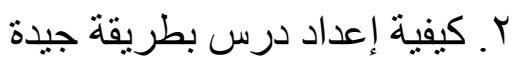

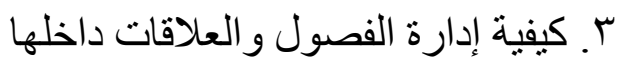

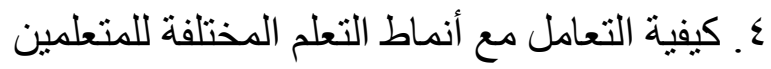

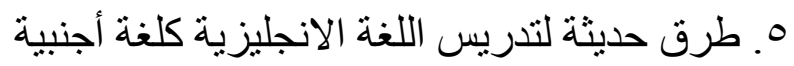

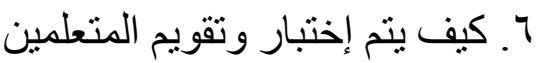

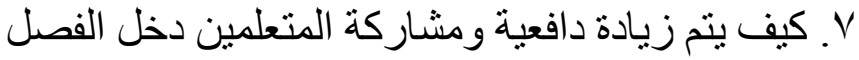

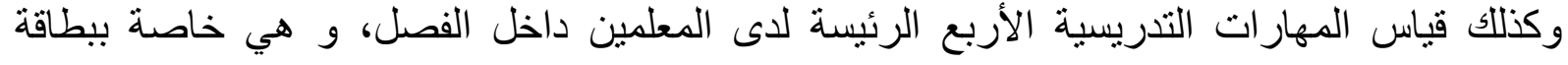

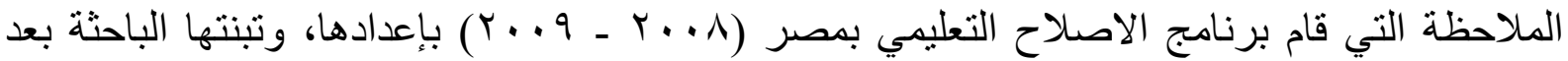

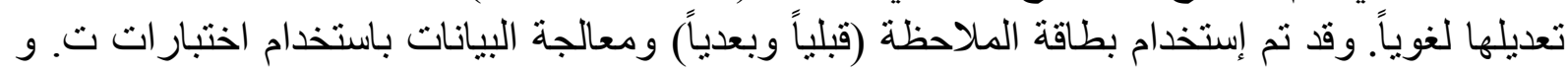

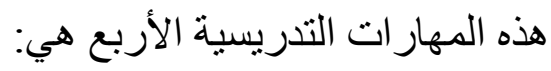

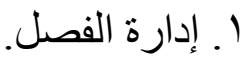

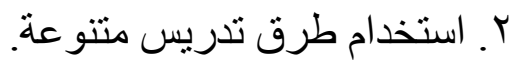

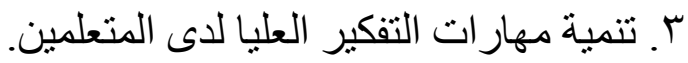
ع. التقويم و تقديم التغذية الراجعة.

الكلمات المفتاحية: بر امج التتمية المهنية / أداء/ الاحتياجات التدريسية. 